\title{
The Immunology of Cancer Cells
}

\author{
Gregory Lee ${ }^{1,2 *}$, Cheng-Yuan Huang1 ${ }^{1}$ Suefay Liu ${ }^{1}$ and Hao Zhang1,2 \\ ${ }^{1}$ UBC Center for Reproductive Health, Vancouver, Canada \\ ${ }^{2}$ Department of Pathology, Shantou University Medical College, Shantou, China
}

Received: November 13, 2013; Accepted: December 13, 2013; Published: December 15, 2013

*Corresponding author: Gregory Lee, UBC Center for Reproductive Health, Vancouver, Canada, Tel: 778-322-4651; E-mail: cyglee@yahoo.com

\begin{abstract}
RP215 is a monoclonal antibody discovered in 1987 which was later found to react specifically with a carbohydrate-associated epitope detected mainly among immunoglobulin heavy chains from cultured cancer cells. With RP215 as the unique probe for cancerous immunoglobulins, the experimental evidences seem to suggest that the immunology of cancer cells plays dramatic roles in the growth/ proliferation and immune protection of cancer cells. RP215-specific cancerous immunoglobulins serve in part to capture or neutralize circulating antibodies or antigen hostile to cancer cells in human body. In the conventional immune system, B and T lymphocytes and their associated antigen receptors play key roles in the adaptive immune response against pathogens and/or cancer cells through established mechanisms. In contrast, cancer cells co-express both $\mathrm{B}$ and $\mathrm{T}$ lymphocyte-associated antigen receptors and immune protection is exercised by completely different mechanisms. For example, these cancer cell-expressed antigen receptors demonstrate a lack of class switching, or limited hyper mutation. Furthermore, toll-like receptors involved in the innate immune system in cancer cells are strongly affected by these cancer cell-expressed antigen receptors. Therefore, both normal and cancerous immune systems can co-exist and can be operated simultaneously within the human body. A potential therapeutic strategy may be developed by using RP215 as a drug candidate to target cancer cells based on these observations.
\end{abstract}

Keywords: Cancerous Immunoglobins; RP215 Monoclonal Antibody; Cancer Immunology; Antigen Receptors.

\section{Abbreviations}

Fuc: Fucose; Gal: Galactose; GalNAc: N-acetylgalactosamine; GlcNAc: N-acetylglucosamine; Hex: Hexose; IgG: Immunoglobulin G; IgM: Immunoglobulin M; Man: Mannose; NeuAc: $\mathrm{N}$-acetylneuraminic acid; NeuGc: N-glycolylneuraminic acid; siRNA: Small interfering ribonucleic acid

\section{Introduction}

The principles and mechanisms of adaptive immunity in the normal immune system have been well established [1]. The antigen receptors of $\mathrm{B}$ and $\mathrm{T}$ cells origins are two key players in fighting off infections/inflammation arising from the invasions of foreign pathogens and/or cancer initiated within the human body environment. B and T cells in our normal immune system may respond to cancer-associated antigens by inducing specific humoral and cellular immune response [1]. The end results may be neutralization or cytotoxic killing of cancer cells within our body environment. However, this process may be only one side of the known actions and has been well accepted in the field of immunology.

Under our normal immune environment, the cancer cells initiated within our body may have also evolved to protect themselves immunologically [2]. Despite many years of studies during the last two decades, little progress has been made regarding the molecular mechanisms of immune protection among cancer cells. The etiology the expression of immunoglobulin in cancer cells remains unknown due to the lack of adequate probes for such investigations [3].

As early as three decades ago, monoclonal antibodies were generated against OC-3-VGH ovarian cancer cells [4]. RP215 was among one of the three thousand selected monoclonal antibodies produced and was later shown to react specifically with a carbohydrate-associated epitope detected mainly on cancer cell-derived immunoglobulin heavy chains but not those of B-cell derived human immunoglobulins (IgG) $[4,5]$. Through years of biological and immunological studies, RP215 was demonstrated to be a suitable alternative for antibodies against antigen receptors or anti-immunoglobulins for mechanistic investigations in the immunology of cancer cells [4 -8].

Through these investigations, it has become apparent that cancerous antigen receptors should, in principle, play certain roles in the growth/ proliferation as well as immune protection by cancer cells [7]. However, the mechanisms of action for the immune protection by cancer cells may not be the same as those established in the normal immune system [1].

Based on these considerations, results of relevant studies are summarized to highlight the possible roles of cancerous immunoglobulins in the immunity of cancer cells. The experimental observations accumulated so far may be sufficient for us to draw a conclusion regarding the mechanisms of immune protection in cancer cells. Therefore, an alternative cancer immune system may be proposed and compared with that of the traditional one. Specially, these cancerous immunoglobulins may play differential roles in immune protection as compared to those of immune surveillance by normal immunoglobulins. Through such comprehensive analyses, a rational approach for anti- 
cancer drug development may be designed for the therapeutic treatment of human cancer in the future $[9,10]$.

\section{Immunoglobulins expressed by normal B-lymphocytes and cancer cells}

Differential Expressions: Expressions of immunoglobulins by normal B lymphocytes are distinctly different from those by cancer cells [11-13]. The characteristic comparisons of these two independent immune systems are summarized in Table 1 [14-18]. Generally speaking, immunoglobulins are expressed by $B$ cells through a long series of interactions with various types of immune cells, such as antigen-presenting cells and/or T cells [1]. These interactions may involve activation, differentiation, antibody expression, and maturation. The molecular mechanisms of antibody productions by B lymphocytes have been well established and include gene conversion, somatic hyper mutation, class switching and maturation [1].

In contrast, cancerous antigen receptors, including immunoglobulins and $\mathrm{T}$ cell receptors, are expressed in a less complicated manner $[19,12,13]$. The incidence of somatic hyper mutation in the variable regions of cancerous immunoglobulins is greatly reduced in comparison to that of normal B lymphocytes $[15,20]$. The number of different immunoglobulins expressed

Table 1: Comparison of Normal and Cancer Immune Systems.

\begin{tabular}{|c|c|c|}
\hline $\begin{array}{l}\text { Structure/ } \\
\text { Functions }\end{array}$ & Normal Immune Cells & Cancer Cells \\
\hline $\begin{array}{l}\text { Expression of } \\
\text { Antigen receptors } \\
{[19]}\end{array}$ & $\begin{array}{l}\text { a. Immunoglobullins } \\
\text { expressed by B- } \\
\text { lymphocytes } \\
\text { b. T cell receptors } \\
\text { expressed by } \\
\text { T-lymphocytes }\end{array}$ & $\begin{array}{l}\text { Both antigen receptors } \\
\text { expressed by cancer } \\
\text { cells of one single clone }\end{array}$ \\
\hline $\begin{array}{l}\text { Class switching of } \\
\text { immunoglobulins } \\
{[14,15]}\end{array}$ & $\begin{array}{l}\text { Class switching of } \\
\text { immunoglobulins; } \\
\text { One single type B cell } \\
\text { can express only one } \\
\text { type of immunoglobin } \\
\text { class and subclass }\end{array}$ & $\begin{array}{l}\text { No class switching; } \\
\text { immunoglobulins of } \\
\text { different classes or } \\
\text { subclasses can be } \\
\text { expressed by cancer } \\
\text { cells from one single } \\
\text { clone }\end{array}$ \\
\hline $\begin{array}{l}\text { Hypermutation in } \\
\text { Variable Regions of } \\
\text { Immunoglobulins } \\
{[14-16]}\end{array}$ & $\begin{array}{l}\text { High frequency of } \\
\text { hypermutation in } \\
\text { the Fab domains of } \\
\text { immunoglobulins } \\
\text { leading to unlimited } \\
\text { diversity of B } \\
\text { lymphocytes }\end{array}$ & $\begin{array}{l}\text { Limited mutations } \\
\text { or diversity in the } \\
\text { variable regions of } \\
\text { immunoglobulins } \\
\text { (less than } 100 \text { detected) }\end{array}$ \\
\hline $\begin{array}{l}\text { Glycosylation } \\
\text { Patterns [17] }\end{array}$ & $\begin{array}{l}\text { No O-linked glycans, and } \\
\text { only one N-glycosylation } \\
\text { at N297 position of IgG } \\
\text { heavy chains; terminal } \\
\text { NeuAc only }\end{array}$ & $\begin{array}{l}\text { Both O-linked and } \\
\text { N-linked glycans are } \\
\text { detected in cancerous } \\
\text { IgG heavy chains; } \\
\text { terminal NeuAc and } \\
\text { NeuGc }\end{array}$ \\
\hline $\begin{array}{l}\text { Interactions with } \\
\text { Toll-like Receptors } \\
\text { (Innate Immunity) } \\
\text { [8] }\end{array}$ & $\begin{array}{l}\text { No known interactions } \\
\text { with toll-like receptors }\end{array}$ & $\begin{array}{l}\text { Strong interaction } \\
\text { with toll-like receptors } \\
\text { within cancer cells }\end{array}$ \\
\hline $\begin{array}{l}\text { Relative } \\
\text { Immunoactivity } \\
{[18]}\end{array}$ & Normal immunoactivity & $\begin{array}{l}\text { Weak immunoactivity } \\
\text { (less than 1-5\%) due to } \\
\text { aberrant glycosylations }\end{array}$ \\
\hline
\end{tabular}

on the surface of cancer cells and the different selected forms are also limited [12]. Immunoglobulins of different classes or subclasses can be expressed simultaneously by cancer cells derived from a single clone [18]. This is in contrast with to normal B lymphocytes. In addition, identical immunoglobulins can sometimes be detected in different cancer tissues among unrelated cancer patients [12].

\section{Differential Glycosylation Patterns of Cancer:}

- N-glycosylation of Cancerous IgG: Glycosylation patterns are quite different between normal and cancerous immunoglobulins $[17,21]$. For example, normal human IgG is generally N-glycosylated at N-297 position in the heavy chain subunit. O-linked-glycosylation among the heavy chain regions of normal IgG is rarely found $[17,21]$. Typically, branched N-linked glycan structures were detected in both normal and cancerous IgG's $[17,21]$. However, additional N-glycan structures, including those of multi-mannose or multi-branched structures, were also identified in cancerous IgG [17]. The results of such comparative analysis are presented in Table 2.

- O-glycosylation of cancerous IgG: Compared to normal human IgG, O-linked glycans can only be detected in cancerous IgG. O-linked glycan analysis and glycopeptide mapping of cancerous IgG were performed with the proposed O-linked glycan structure/compositions presented in Table 3. These 0-glycans were obtained from CA215 and/or cancerous IgG isolated independently from OC-3-VGH (ovary) and C-33A (cervix) cancer cell lines [17]. Enzyme immunoassay kit for normal human IgG was employed to determine the relative immunoactivity of normal human IgG and affinity-purified cancerous IgG. Unexpectedly, cancerous IgG exhibited much lower immunoactivity when compared with that of normal IgG. This phenomenon can only be explained by the aberrant glycosylation. Apparently, the aberrant glycosylations can result in significant alterations in the protein structures or conformations and thus reduce immunobinding activity [18].

\section{Functional Analyses of Cancerous Immunoglobulins}

The biological and immunological properties of normal human immunoglobulin have been known for decades [1]. These immunoglobulins may serve as one of the antigen receptors or as antibodies to neutralize foreign pathogens and cancer cells which are initiated within the body environment $[5,22,23]$. In contrast, cancerous immunoglobulins may be required for immune protection, and serve in part to defend against immune surveillance by the body's immune system $[2,3]$.

Detection of Circulating "Antigens" Recognized by Cancerous Immunoglobulins:

- Since RP215 reacts mainly with the heavy chains of cancerous immunoglobulins, the corresponding antigen designated as CA215 can be isolated in sufficient quantity [18]. CA215 can serve as an adequate ligand to capture circulating "antigen" which can be recognized by cancerous 
Table 2: Profile of N-linked Glycans Unique to CA215 or cancer IgG, but not in normal human IgG.

\begin{tabular}{|c|c|c|}
\hline Observed Mass m/z & Charge state & Proposed Structure \\
\hline$[\mathrm{M}+\mathrm{Na}]^{+}+$ & {$[\mathrm{M}+2 \mathrm{Na}] 2+$} & \\
\hline 1169 & Double & $\mathrm{GlcNAc}_{5} \mathrm{Man}_{3} \mathrm{Hex}_{2}$ \\
\hline 1172 & Single & $\mathrm{GlcNAc}_{2} \mathrm{Man}_{3}$ \\
\hline 1330 & Double & $\mathrm{GlcNAc}_{4} \mathrm{Man}_{3} \mathrm{Hex}_{2} \mathrm{Fuc}_{1} \mathrm{NeuGc}_{1}{ }^{\mathrm{a}}$ \\
\hline $1366^{\mathrm{a}}$ & Double & $\mathrm{GlcNAc}_{5} \mathrm{Man}_{3} \mathrm{Hex}_{2} \mathrm{NeuGc}_{1}$ \\
\hline $1438^{\mathrm{a}}$ & Double & $\mathrm{GlcNAc}_{4} \mathrm{Man}_{3} \mathrm{Hex}_{2} \mathrm{NeuGc}_{2}$ \\
\hline $1467^{\mathrm{a}}$ & Double & $\mathrm{GlcNAc}_{5} \mathrm{Man}_{3} \mathrm{Hex}_{3} \mathrm{NeuGc}_{1}$ \\
\hline 1498 & Double & GlcNAc $_{6} \mathrm{Man}_{3} \mathrm{Hex}_{4}$ \\
\hline $1525^{a}$ & Double & $\mathrm{GlcNAc}_{4} \mathrm{Man}_{3} \mathrm{Hex}_{2} \mathrm{Fuc}_{1} \mathrm{NeuGc}_{2}$ \\
\hline 1580 & Single & $\operatorname{GlcNAc}_{2} \operatorname{Man}_{5}^{\mathrm{b}, \mathrm{c}}$ \\
\hline 1621 & Single & $\mathrm{GlcNAc}_{3} \mathrm{Man}_{3} \mathrm{Hex}_{1}$ \\
\hline $1785^{b}$ & Single & $\mathrm{GlcNAc}_{2} \mathrm{Man}_{6}$ \\
\hline
\end{tabular}

${ }^{\mathrm{a} O M}$ with NeuGc as the terminal sialic acid.

${ }^{\mathrm{b}} \mathrm{OM}$ with high mannose structure.

'Lots CA215A and CA215B (acid-eluted) were used for analysis.

Obtained from [17] with permission.

Table 3: Comparative Profiles of Permethylated O-linked Glycans of Five Different CA215 Samples Which Consist Mainly of Cancerous IgG.

\begin{tabular}{|l|c|c|}
\hline \multicolumn{1}{|l|}{} & $\begin{array}{c}\text { Observed } \\
\text { Mass } \\
\mathbf{m} / \mathbf{z} \\
\text { Sample ID }\end{array}$ & $\begin{array}{c}\text { Proposed Structure } \\
\text { Structure }\end{array}$ \\
\hline CA215 (lots: A, B, and C) & 534 & GalNAc1Gal1 \\
\hline CA215 (lots: A and B) & 708 & GalNAc1Gal1Fuc1 \\
\hline $\begin{array}{l}\text { CA215 (lots: A, B, D, C, E, } \\
\text { and F) }\end{array}$ & 896 & GalNAc1Gal1NeuAc1 \\
\hline CA215 (lots: C, E, and F) & 926 & GalNAc1Gal1NeuGc1 \\
\hline CA215C & $940^{c}$ & GalNAc1GlcNAc1NeuAc1 \\
\hline CA215(lots: A, B, and C) & 1140 & GalNAc1GlcNAc1Gal1NeuAc \\
\hline CA215 (lots: C, D, E, and F) & 1257 & GalNAc1Gal1NeuAc2 \\
\hline CA215 (lots: C, E, and F) & 1317 & GalNAc1Gal1NeuGc2 \\
\hline CA215 (lots: A, B, C, E, & 1345 & GalNAc1GlcNAc1Gal2NeuAc \\
\hline and F) & 1375 & GalNAc1GlcNAc1Gal2NeuGc \\
\hline CA215 (lots: C, E, and F) & \\
\hline
\end{tabular}

${ }^{\mathrm{a} C A 215}$ lots A, B and C were from OC-3-VGH ovarian cancer cells (CA215OC-3) lots A and B were obtained through acid elution, whereas lots $C, D$, $\mathrm{E}$ and $\mathrm{F}$ were obtained through elution with $3 \mathrm{M}$ urea.

${ }^{b}$ Lot CA215D was obtained by an additional purification of urea-eluted CA215 (S15K-100425) with goat anti-human IgG affinity column followed by the same analysis (CA215D is designated as affinity-purified cancerous IgG). CA215 lots E and F were from C-33A cervical cancer cells (CA215-C33A).

'Detected by MALDI-TOF MS method but not found by NSI-MS method.

${ }^{\mathrm{d}} \mathrm{N}$-acetylgalactosamine $(\square), \mathrm{N}$-acetylglucosamine $(\boldsymbol{\square})$, Fucose $(\boldsymbol{\Delta})$, Galactose $(\bullet), N$ - acetylneuraminic acid $(\bullet)$ and N-glycolylneuraminic acid $(\bullet)$.

Obtained from [17] with permission. immunoglobulins through specific immunobinding. By using CA215 affinity chromatography, relevant antigen can be isolated from pooled human specimens. The isolated "antigen" can then be characterized through biochemical and immunological analysis. Attempts are being made to elucidate molecular mechanisms of immune protection by cancer cells [6-8]. Based on results our preliminary analysis, pooled normal human serum specimens were found to show affinity to CA215 and/ or cancerous immunoglobulins oGu \& Lee, unpublished observations). It remains to be demonstrated if these CA215 (or cancerous immunoglobulins) cross-reacting proteins or antibodies are those recognizing cancerassociated antigens identified in serum samples of general population in humans.

- Roles of Cancerous Immunoglobulins in the Growth/ proliferation of Cancer Cells: Based on previous experimental observation by several laboratories, it has been generally accepted that the expressions of cancerous immunoglobulins on the surface of cancer cells may be required for growth/proliferation of cancer cells $[2,3,8]$. Knock down of cancerous IgG expression by transfection with IgG-related siRNA or siRNA plasmids could result in retarded or inhibited growth of cancer cells in vitro and in vivo $[3,24]$. Blocking of surface bound immunoglobulins with specific antibodies such as RP215, as well as antihuman IgG or anti-T cell receptors, was also found to result in induced apoptosis of cancer cells in vitro [6-8]. Complement-dependent cytotoxicity can also be induced in cancer cells with antibodies against the surface-bound receptors. Furthermore, RP215 was also demonstrated to cause tumor volume reductions in nude mouse models [22].

Effects of RP215 and antibodies against antigen receptors on the gene expression of cancer cells have been investigated [8]. It was generally observed that selected genes involved in growth/ regulation of cancer cells are strongly influenced by antibody binding to surface antigen receptors. Their effects on the gene regulations of cancer cells are highly correlated, indicating the biosimilarity of these three ligands [8]. They also have strong effects on the regulations of the toll-like receptors in the innate immune system of cancer cells. All of these experimental observations are consistent with the protective roles of antigen receptors in cancer cells, especially their growth and proliferation within the normal immune environment.

Compared to the unique functional properties of cancerous immunoglobulins, none of these factors are found to operate similarly in the normal immune system [1]. This phenomenon makes the cancer immunity uniquely different from that of traditional immune system established so far (Table 1).

\section{Conclusion}

In this mini-review, scientific information has been presented to highlight the fundamental differences between the traditional normal immune system and the cancer immune system. These 
differences may stem from the evolution of different organisms. We believe that in higher organisms such as mammals, two separate immune systems should exist independently to perform differential functions of immune surveillance and immune protection in our body environment. The growth/ proliferation of cancer cells depends highly on the balance of these two opposite factors inside the body. Only when the detailed molecular interactions between cancerous immunoglobulins and the complicated body immune system are completely resolved, immunotherapy of human cancer may have a better chance of success.

\section{Acknowledgements}

This research project was supported in parts by NRC-IRAP program (\#794354) of Canada and the NSERC summer student scholarship to Suefay Liu of McGill University. The editorial assistance of Dr. Chichi Liu and technical support of Yiting Tang is acknowledged. Initial observations of circulating " antigen" in human serum were made in Dr. Jiang Gu's lab at Shantou University, Shantou, China. Helpful discussion on this topic with Dr. Gu is acknowledged.

\section{Conflict of interest}

Gregory Lee is co-founder of Vancouver BioTech Ltd. The others have nothing to declare.

\section{References}

1. Murphy K, Travers P, \& Walport M. (2008). The Adaptive Immune Response. In: Janeway's Immunobiology ( $7^{\text {th }}$ Ed.) Part IV. (7th ed., pp. 323-496). Garland Science, Taylor \& Francis Group.

2. Chen $\mathrm{Z}, \& \mathrm{Gu} J$ (2007) Immunoglobulin $\mathrm{G}$ expression in carcinomas and cancer cell lines. FASEB J, 21(11): 2931-2938.

3. Qiu X, Zhu X, Zhang L, Mao Y, Zhang J. et al. (2003) Human epithelial cancers secrete immunoglobulin $G$ with unidentified specificity to promote growth and survival of tumor cells. Cancer Research, 63(19): 6488-6495.

4. Lee CY, Chen KW, Sheu FS et al. (1992) Studies of a tumor-associated antigen, COX-1, recognized by a monoclonal antibody. Cancer Immunology, Immunotherapy, 35(1): 19-26.

5. 5. Lee G, Laflamme E, Chien CH, \& Ting HH (2008) Molecular identity of a pan cancer marker, CA215. Cancer biology \& therapy, 7(12): 2007-2014

6. Lee G (2012a) Cancerous immunoglobulins and CA215: implications in cancer immunology. American Journal of Immunology, 8(4):101116.

7. Lee G, Liu S (2013) Roles of antigen receptors and CA215 in the innate immunity of cancer cells. Open Journal of Immunology,3(3): 127-138.

8. Tang Y, Zhang H, \& Lee G (2013) Similar gene regulation patterns for growth inhibition of cancer cells by RP215 or anti-antigen receptors. Journal of Cancer Science \& Therapy, 5: 200-208.

9. Lee G, Zhu M, \& Ge B (2012b) Potential Monoclonal Antibody Therapy for the Treatment of Ovarian Cancer. In Farghaly, S. A (Ed.) , ( pp. 385-
406). Ovarian Cancer-Basic Science Perspective. Vancouver: InTech.

10. Lee G, Cheung A, Ge B, Zhu M. et al. (2012c) CA215 and GnRH receptor as targets for cancer therapy. Cancer Immunology, Immunotherapy, 61(10): 1805-1817.

11. Babbage G, Ottensmeier CH, Blaydes J, Stevenson FK, \& Sahota S (2006) Immunoglobulin heavy chain locus events and expression of activation-induced cytidine deaminase in epithelial breast cancer cell lines. Cancer Research, 66(8): 3996-4000.

12.Zheng J, Huang J, MaoY, Liu S, Sun X, et al. (2009) Immunoglobulin gene transcripts have distinct $\mathrm{V}_{\mathrm{H}} \mathrm{DJ}_{\mathrm{H}}$ recombination characteristics in human epithelial cancer cells. Journal of Biological Chemistry, 284(20): 13610-13619.

13.Zhu X, Wu L, Zhang L, Hao P, Zhang S, et al. (2010) Distinct regulatory mechanism of immunoglobulin gene transcription in epithelial cancer cells. Cellular and Molecular Immunology, 7(4): 279-286.

14. Early P, Huang H, Davis M, Calame K,\& Hood L (1980) An immunoglobulin heavy chain variable region gene is generated from three segments of DNA: $\mathrm{V}_{\mathrm{H}^{\prime}}$ D and $\mathrm{J}_{\mathrm{H}^{\prime}}$ Cell, 19(4): 981-992.

15. Honjo T, Kinoshita K, Muramatsu M (2002) Molecular mechanism of class switch recombination: Linkage with somatic hypermutation. Annual Review of Immunology, 20: 165-196.

16. Jung D, Giallourakis C, Mostoslavsky R, \& Alt F (2006) Mechanism and control of V(D)J recombination at the immunoglobulin heavy chain locus. Annual Review of Immunology, 24: 541-570.

17. Lee G, Azadi P (2012d) Peptide mapping and glycoanalysis of cancer cell-expressed glycoproteins CA215 recognized by RP215 monoclonal antibody. International Journal of Carbohydrate Chemistry, 31(1): 1030 .

18. Lee G, Cheung AP, Li B, Ge B, \& Chow PM, (2012e) Molecular and immuno-characteristics of immunoglobulin-like glycoproteins in cancer cell-expressed biomarker, CA215. Immunological Investigations,41(4): 429-446.

19. Lee G, Zhu M, Ge B, Potzold S (2012f) Wildspread expressions of immunoglobulin super family proteins in cancer cells. Cancer Immunology, Immunotherapy,61(1): 89-99.

20. Dudley D D, Chaudhuri J, Bassing CH, \& Alt FW (2005) Mechanism and control of V(D)J recombination versus class switch recombination: Similarities and differences. Advances in Immunology, 86: 43-112.

21. Arnold J N, Wormald MR, Sim RB, Rudd PM, \& Dwek RA (2007) The impact of glycosylation on the biological function and structure of human immunoglobulins. Annual Review of Immunology, 25: 21-50.

22. Lee G, Chu RA, \& Ting HH (2009) Preclinical assessment of anti-cancer drugs by using RP215 monoclonal antibody. Cancer Biology Therapy, 8(2):161-166.

23. Lee G, \& Ge B (2010) Inhibition of in vitro tumor cell growth by RP215 monoclonal antibody and antibodies raised against its anti-idiotype antibodies. Cancer Immunology, Immunotherapy, 59(9): 1347-1356.

24. Hu D, Duan Z, Li M, Jiang Y, Liu H, et al. (2011) Heterogeneity of aberrant immunoglobulin expression in cancer cells. Cellular \& Molecular Immunology, 8(6): 479-485. 